\title{
First report of Alternaria alternata causing leaf spot on Rumex vesicarius in India
}

\author{
N. Ravi Sankar • M. Nagalakshmi Devamma • \\ D. Giridhar
}

Received: 18 October 2011 / Accepted: 21 November 2011 /Published online: 9 December 2011

(C) Australasian Plant Pathology Society Inc. 2011

\begin{abstract}
A severe outbreak of leaf spot was observed on Rumex vesicarius for the first time in Andhra Pradesh state of India during 2009 to 2011. Based on pathogenicity, morphology and rDNA spacer sequences, the pathogen was identified as Alternaria alternata (Fr.) Keissler. This report is the first of Alternaria leaf spot of Rumex vesicarius.
\end{abstract}

Keywords Rumex vesicarius Alternaria alternate .

Pathogenicity $\cdot$ rDNA spacer sequence

Rumex vesicarius $\mathrm{L}$ is an annual, glabrous herb of the Polygonaceae, native to northern Africa and Asia (Pakistan and India), and is distributed widely in the tropics as an ornamental. It is also known as bladder dock, rosy dock, blister sorrel or country sorrel and is mostly cultivated as a leafy vegetable. This crop is widely used in the cuisine of different regions for its thick, semisucculent leaves, mild flavour, and mucilaginous texture. In south India, $R$. vesicarius is extensively grown for local markets and regional export. For the last 2 years (2009 to 2011), during rainy seasons (June to September), severe foliar symptoms were observed on Rumex vesicarius in Ranga Reddy, Chittoor

N. R. Sankar $(\bowtie) \cdot$ M. N. Devamma

Applied Plant Pathology Laboratory, Department of Botany, Sri Venkateswara University,

Tirupati 517 502, Andhra Pradesh, India

e-mail: nrsr2008@yahoo.com

N. R. Sankar • D. Giridhar

Microbiology Laboratory, Global Institute of Biotechnology,

Hyderabad 500 029, Andhra Pradesh, India and Kadapa districts of Andhra Pradesh, India. Approximately 60 to $75 \%$ of the fields were affected with disease incidence ranging from 70 to $90 \%$. Symptoms initially appeared as small light brown, circular spots with becoming irregular, dark brown lesions, while a few remained circular with concentric rings or zones (Fig. 1). On severely affected leaves several spots coalesced to form large necrotic areas (2 to $23 \mathrm{~mm}$ in diameter), ultimately leading to drying of the leaves. The disease first appeared in June, was widespread from the end of July through August when temperatures ranged from 25 to $30^{\circ} \mathrm{C}$, and ended in September. Diseased leaves were cut into small fragments, surface sterilized in $1 \%$ sodium hypochlorite for $2 \mathrm{~min}$, rinsed three times in sterile distilled water, and plated on potato dextrose agar (PDA), and then incubated at $25^{\circ} \mathrm{C}$ for 7 days under $12 \mathrm{~h}$ light and dark conditions. Hyphal tips from the margin of each developing colony were subcultured on PDA. Fungal colonies were initially white, becoming olivaceous, and turning brown with age. Conidiophores were short, simple or branched, golden brown in colour, measuring $15 \mu \mathrm{m}$ long and 2-6 $\mu \mathrm{m}$ thick. Conidia were obclavate, obpyriform or ellipsoidal with a short conical beak, and borne in long chains, branched or unbranched, pale brown to golden brown and 22 to $32 \mu \mathrm{m}$ long and 13 to $18 \mu \mathrm{m}$ wide at the broadest point. Conidia had 3 to 8 transverse septa and 1 to 2 longitudinal septa (Fig. 2). On the basis of conidial morphological characteristics, the pathogen was identified as Alternaria alternata (Fr.) Keissler (Simmons 2007). Identification was confirmed by amplification of the internal transcribed spacer (ITS) region. Genomic DNA was extracted from pure cultures of an isolate and the internal transcribed spacer (ITS) region was amplified using the primers ITS4 and ITS5 (White et al. 1990). PCR amplicons 


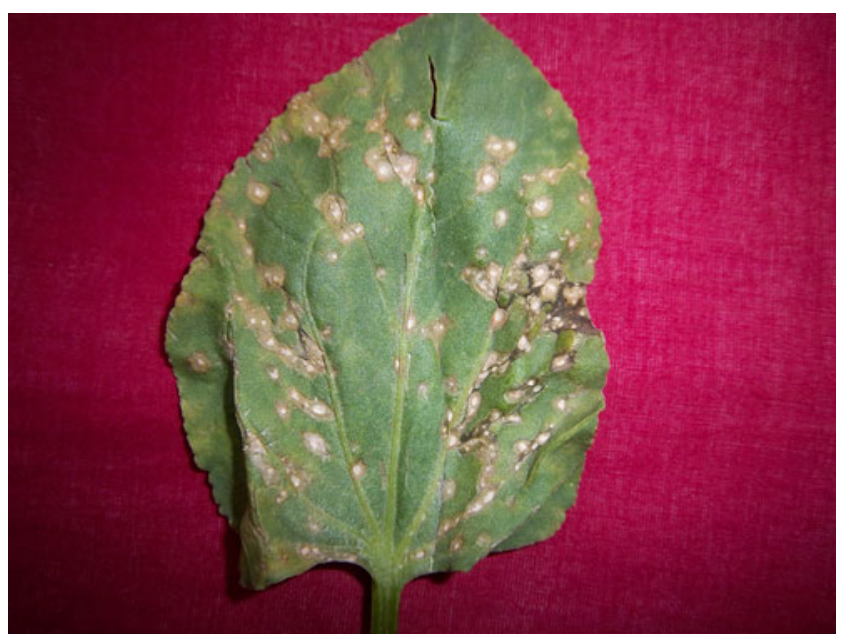

Fig. 1 Leaf spot symptoms on R. vesicarius

of approximately $488 \mathrm{bp}$ were obtained from isolate, and sequence comparisons with GenBank showed 100\% similarity with A. alternata (GenBank Accession No. JF266575.1). Sequence from this study was submitted to GenBank nucleotide database (GenBank Accession No. AB675593). Moreover, Alternaria alternata has been deposited in the fungal identification service, (MACS-ARI), Agharkar Research Institute, Pune, India (Accession No. NFCCI-2637).

To determine pathogenicity, inoculations were performed on detached, surface sterilized, healthy leaves

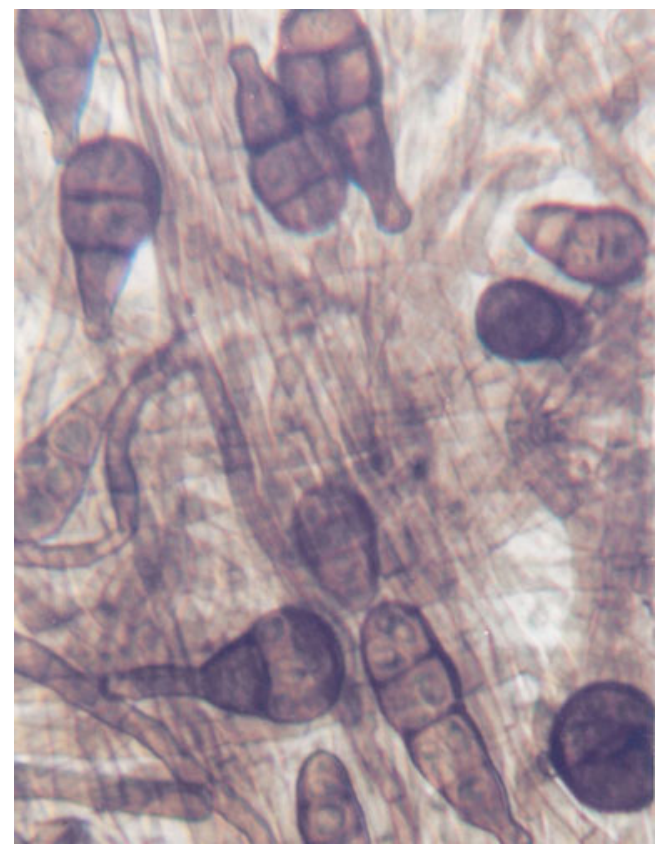

Fig. 2 Conidia of $A$. alternata (scale bar $=20 \mu \mathrm{m})$ following the method of Belisario et al. (1999). A 5- $\mu \mathrm{l}$ drop of conidial suspension containing $1 \times 10^{5} \mathrm{CFU} / \mathrm{ml}$ was placed on each leaf and 12 leaves per isolate were used. Leaves were incubated in a growth chamber $(90 \%$ relative humidity and a 12-h photoperiod). After 7 days, leaf spots similar to the original symptoms developed on all inoculated leaves and A. alternata was consistently re-isolated from symptomatic tissue, fulfilling Koch's postulates. Control leaves inoculated with sterile distilled water remained asymptomatic. $R$. vesicarius has been reported to be affected by leaf rust caused by Uromyces longipedicellaris (Ramachar and Rao, 1984) in India. A. alternata is a widespread pathogen affecting a wide range of hosts, and has previously been reported on apple (Johnson et al. 2000), citrus (Peever et al. 2002), tomato (Akhtar et al. 2004), Stevia rebaudiana (Maiti et al. 2006), Rumex dentatus (Siddiqui et al. 2009) and pomegranate (Ezra et al. 2010), but a new record as a plant pathogen on $R$. vesicarius is very significant. Thus, leaf spot on $R$. vesicarius caused by A. alternata is the first report from India and worldwide.

\section{References}

Akhtar KP, Saleem MY, Asghar M, Haq MA (2004) New report of Alternaria alternata causing leaf blight of tomato in Pakistan. New Disease Reports 9:43

Belisario A, Forti E, Corazza L, Van Kesteren HA (1999) First report of Alternaria alternata causing leaf spot on English walnut. Plant Disease 83:696

Ezra D, Gat T, Skovorodnikova Y, Vardi Y, Kosto I (2010) First report of Alternaria black spot of pomegranate caused by Alternaria alternata in Isreal. Australasian Plant Disease Notes 5:1-2

Johnson RD, Johnson L, Kohmoto K, Otani H, Lane CR, Kodama M (2000) A polymerase chain reaction-based method to specifically detect Alternaria alternata apple pathotype (A. mali), the causal agent of Alternaria blotch of apple. Phytopathology 90:973-976

Maiti CK, Sen S, Acharya R, Acharya K (2006) First report of Alternaria alternata causing leaf spot on Stevia rebaudiana. New Disease Reports 14:22

Peever TL, Ibanez A, Akimitsu K, Timmer LW (2002) Worldwide phylogeography of the citrus brown spot pathogen, Alternaria alternata. Phytopathology 92:794-802

Ramachar P, Rao AS (1984) Uromyces longipedicellaris, new species on Rumex vesicarius L. Kavaka 12(2):71-72

Siddiqui I, Bajwa R, Javid A (2009) First report of Alternaria alternata causing leaf spot on Rumex dentatus in Pakistan. Plant Disease 93:431

Simmons EG (2007) Alternaria: An identification manual. The American Phytopathological Society, St. Paul

White TJ, Bruns T, Lee S, Taylor J (1990) Amplification and direct sequencing of fungal ribosomal RNA genes for phylogenetics. In: Innis MA, Gelfand DH, Sninsky JJ, White TJ (eds) PCR protocols. A guide to methods and applications. Academic, San Diego, pp 315-322 